\title{
Article
}

\section{Socio-economic condition of fish farmers of Jhikargachha upazila in Jessore district, Bangladesh}

\author{
Abdulla-Al-Asif ${ }^{1,2 *}$ and Md. Ahsan Bin Habib ${ }^{1}$ \\ ${ }^{1}$ Department of Aquaculture, Faculty of Fisheries, Bangladesh Agricultural University, Mymensingh-2202, \\ Bangladesh \\ ${ }^{2}$ Department of Fisheries and Marine Bioscience, Faculty of Biological Science and Technology, Jessore \\ University of Science and Technology, Jessore-7408, Bangladesh
}

*Corresponding author: Abdulla-Al-Asif, Department of Aquaculture, Faculty of Fisheries, Bangladesh Agricultural University, Mymensingh-2202, Bangladesh. Phone: +8801716838294; E-mail: jessoreboyhemel@gmail.com

Received: 07 December 2017/Accepted: 24 December 2017/ Published: 28 December 2017

\begin{abstract}
The present study was conducted to assess the livelihood status of fish farmers and socioeconomic condition in the Jhikargachha upazila, Jessore, Bangladesh. Data were collected from 50 fish farmers for a period of six months from June 2016 to November 2016. The study indicated that $38 \%$ of the farmers were in age structure of 50-60 years, 44 farmers (88\%) were Muslims and others Hindu (12\%). About 82\% farmers had a primary occupation of agriculture and others were involved in business $(8 \%)$, service (4\%) and politics (4\%). It was found that, $66 \%$ farmers had joint family and others lived in separated family (34\%). Majority (44 farmers) respondents had concrete house and rest of (6 farmers) had semi-concrete house. Almost (44\%) farmers used concrete toilet and rest of farmers used semi-concrete (56\%). All the respondents used to drink tube well water for drinking and other household works. Out of 50 fish farmers, $4 \%$ had no education (illiterate), $36 \%$ had primary education, $42 \%$ secondary level (Up to X), $10 \%$ S.S.C., $4 \%$ H.S.C. and $4 \%$ bachelor level of education. In the study area, $32 \%$ of the farmers had ponds of $34-66 \mathrm{dec}, 28 \%$ had pond of $15-33 \mathrm{dec}, 14 \%$ had ponds of up to $100 \mathrm{dec}, 22 \%$ had ponds of $101-330 \mathrm{dec}$ and $4 \%$ had ponds of 330-above dec. It was found that, $62 \%$ farmers had training on fish farming and rest $38 \%$ farmers had no training on fish farming. Among 50 farmers $64 \%$ farmers were found used to invest their own credit and rest $36 \%$ farmers took loan from bank, NGO, money lender and broker agency. Most of the farmers were interested to stock rui, catla and mrigal and other species. In the study area, cow dung was used by 50 (100\%) of farmers, 47 farmers used urea, 40 farmers used TSP and 34 farmers used MoP. It was found that, 40\% farmers produced fish between $1001 \mathrm{~kg}-2000$ $\mathrm{kg} /$ year and 17 (34\%) farmers produced $3001 \mathrm{~kg}$-above/year. The highest income was 3,30,75,000Tk/Year and the lowest income from a pond was $20000 \mathrm{Tk} /$ Year. In the study area, every farmer had at least one mobile phone. Almost $96 \%$ farmers were used to go MBBS doctor and only $4 \%$ to homeopathic treatment.
\end{abstract}

Keywords: socio-economic study; fish farmer; Jhikargachha upazila; Jessore

\section{Introduction}

As a member of south Asian country, Bangladesh is an agrarian, highly populated developing country and the nation striving hard for rapid development of its economy. Critics showed that the future economic and social advancement of the country is highly depends on the agricultural sectors and plays a vital role in the socioeconomic blossoming of rural area, carry out the animal protein demand, creating new employment opportunity, eradication of poverty and earning foreign exchange for the national economy. About 2.7 million people are directly employed in this sector and another 17.80 million people indirectly earn their livelihood indirectly involving activities related to fisheries (DoF, 2015). At present fisheries and aquaculture contributes 3.69\% to 
national GDP and 2.01\% to foreign exchange earnings through export (Export Promotion Bureau, 2014). Fisheries sectors contributed to agricultural GDP as 23.12\% (Bangladesh Economic Review, 2015). In fish production was 3,68,4894 MT in 2014-15 fiscal years. Fish also contributed about $60 \%$ to the nation's animal protein intake during 2013-14. At present annual fish intake by an individual is $19.34 \mathrm{~kg}$ and the annual fish demand is 3.09 million metric tons (DoF, 2015). So malnutrition problem can be reduced by increasing the production of fish. Fisheries sector creates 1.4 million full time employments and nearly 11 million part time employments (Haque et al, 1991). A large portion of rural family members are engaged in part time fishing from the beels (Hughes et al., 1994). It creates diverse livelihood opportunities for a number of people, many of whom living below the poverty level, in the form farmers, operators, employees, traders, intermediaries, day laborers and transporters (Ahmed and Rahman 2005). Pond fish farming has been proved to be a profitable business than rice cultivation. So many farmers in rural areas are converting their rice field into aquaculture pond (Islam et al., 2002). Many pond fish farmers in rural areas have taken fish farming activities as their secondary occupation and most of the people involved in fish farming improved their socioeconomic condition through pond fish farming activities (Ara, 2005). Bangladesh has got a large number of ponds scattered all over in the country. There are 47, 08,193 ha water bodies of which 3, 77,968 ha ponds are suitable for fish culture (BBS, 2014 and DoF, 2015). It has been estimated that about 1.28 million people are directly related to fishing activities (Mahfuj et al., 2012). For sustainable rural development and poverty elimination, different approaches have been adopted and the "Sustainable Livelihood Approach" has been gradually expanded with its own core and principles for poverty focused development activities (DFID, 1998). A sustainable livelihood approach is a way of thinking about the objectives, scope and priorities for development. Considering the financial hardship and other complexities of the rural fish farmers, it is important to analyze their livelihood status. In near present years further improvement in pond aquaculture has gained due to application of technique by introducing scientific strategies of pond preparation (liming, repair dam), species selection, stocking density, feed application, fertilizers, water exchange and proper management. This scientific knowledge is gain by the fish farmer in upazila fisheries office and local NGOs. In the recent year fish farming activities are gradually increase in Jhikargachha upazila. Most of the farmer followed two types of culture technique are characterized by extensive (traditional) and improved traditional (semi-intensive) system. The present study was planned to know the status of fish culture in ponds of the study area. Therefore, the present study was done with the objectives to investigate the fish culture strategy and management in some selected area of Jhikargachha upazila under Jessore district and to know the socio-economic condition of involved fish farmer.

\section{Materials and Methods}

\subsection{Study area and periods}

The study was conducted in some selected areas of Jhikargachha upazila during June to November, 2016 by using survey and frequent interview method. Fifty fishermen of the area were interviewed during the survey. The study was carried out in the five unions named Navaran, Nirbashkhola, Hazaribagh, Shankarpur and Bankra (Figure 1).

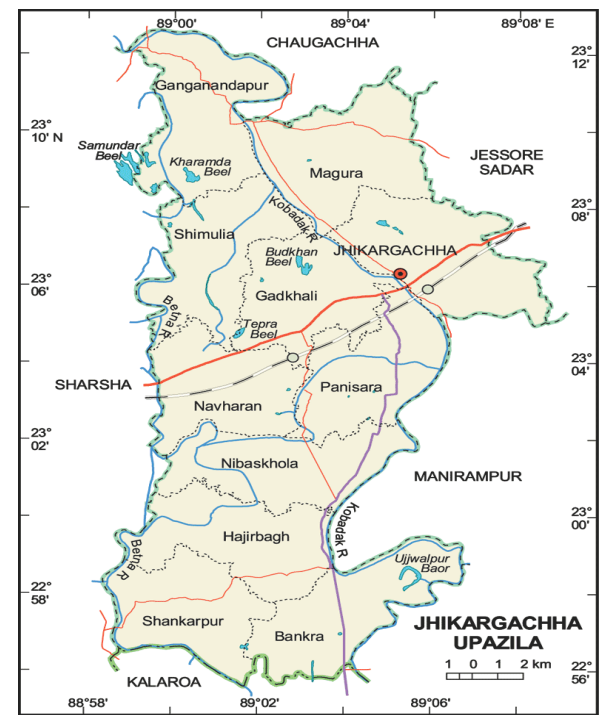

Figure 1. Map of Jhikargachhaupazila showing the study area. 


\subsection{Target group}

Total 50 farmers from five unions (10 farmers from each union) in Jhikargachha upazila were selected purposively.

\subsection{Data collection}

\subsubsection{Primary sources}

The questionnaire interviews were the primary sources of acquired data. Interviews were conducted at the pond sites and home in the selected area. At the time of interview, the physical conditions of the ponds and the fish cultivation methods like pond repairing, application of food and fertilizers, harvesting, etc. were observed for well understanding the fish production technology in the study area. Time required for each interview was about an hour to one and half hour.

\subsubsection{Secondary sources}

The secondary sources of data were central library, Bangladesh Agricultural University, Mymensingh; different websites and journals; Upazila Fisheries Office, Jhikargachha and District Fisheries Office, Jessore.

\subsection{Data processing and analysis}

After collection of data from the field, data were verified to eliminate errors and inconsistencies. Then the data were tabulated carefully. The qualitative data were categorized and analyzed mainly based on descriptive statistical analysis using MS excel.

\section{Results}

\subsection{Age structure of fish farmers in Jhikargachha, Jessore}

In the study area, majority of fish farmers (38\%) were 50-60 years old. On the other hand, $30 \%$ respondents were less than 40 years old and $32 \%$ respondents were $40-50$ years old (Table 1).

Table 1. Age of the fish farmers in Jhikargachhaupazila, Jessore.

\begin{tabular}{lll}
\hline Age group (years) & No. of respondents & Respondents (\%) \\
\hline $30-40$ & 15 & 30 \\
$41-50$ & 16 & 32 \\
$51-60$ & 19 & 38 \\
Total & $\mathbf{5 0}$ & $\mathbf{1 0 0}$ \\
\hline
\end{tabular}

\subsection{Religion status}

It was recorded that $44(88 \%)$ farmers were Muslim and 6 (12\%) farmers were Hindu (Figure 2).

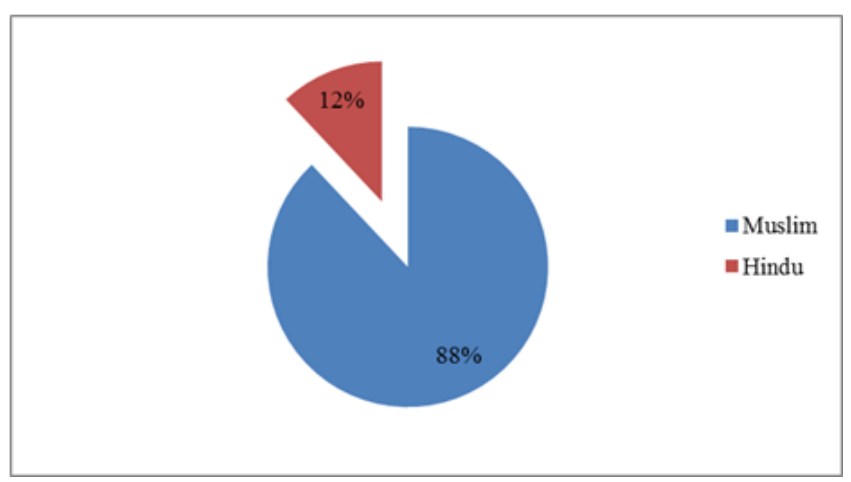

Figure 2. Religion status of fish farmer in Jhikargachha upazila, Jessore.

\subsection{Primary occupation of fish farmers}

According to the survey, the fish farmers were found to be involved in activities such as agriculture (82\%), business (8\%), service (4\%) and politics (4\%) and rest (2\%) as daily labor work (Figure 3). 


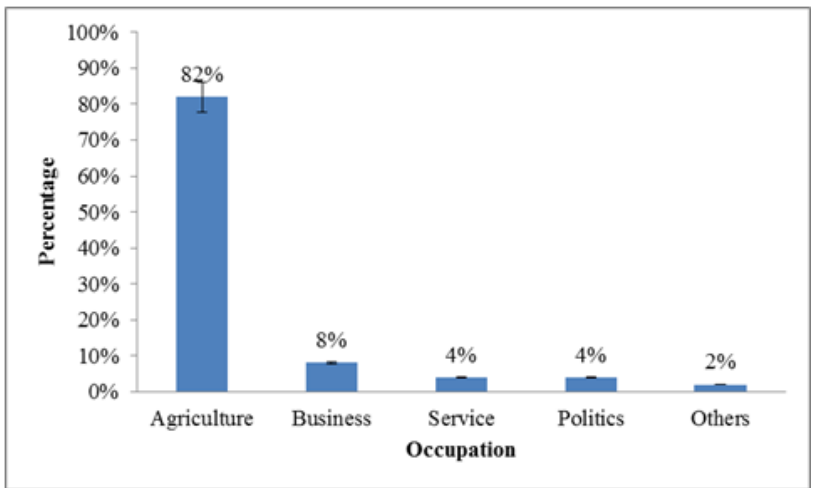

Figure 3. Primary occupation of fish farmers.

\subsection{Family type}

It was found that $66 \%$ fish farmers lived in joint families and $34 \%$ lived with separated families (Table 2).

Table 2. Family type of fish farmers in Jhikargachha upazila, Jessore.

\begin{tabular}{lll}
\hline Family type & No. of respondents & Respondents (\%) \\
\hline Joint & 33 & 66 \\
Separated & 17 & 34 \\
Total & $\mathbf{5 0}$ & $\mathbf{1 0 0}$ \\
\hline
\end{tabular}

\subsection{Family member}

It was found that around 13 (26\%) families had four members, 9 (18\%) families had five members, $16(32 \%)$ families had six members and $12(24 \%)$ families had seven or more members in their family in the study area (Figure 4).

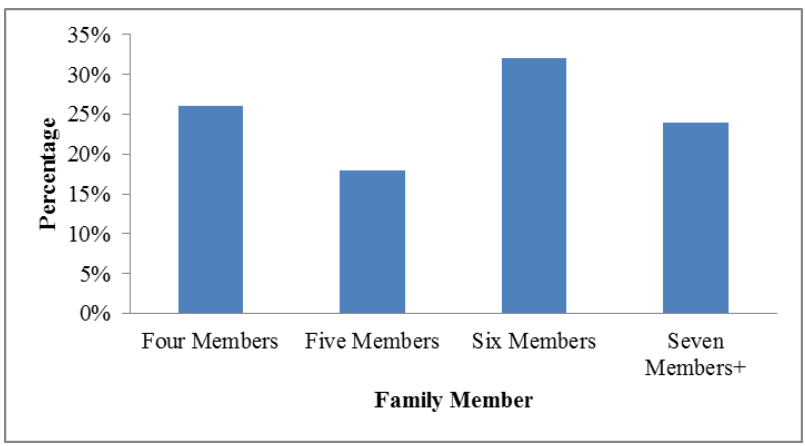

Figure 4. Family member percentage of fish farmers.

\subsection{Housing condition of fish farmers}

Majority respondents around $44(88 \%)$ had concrete house (Concrete wall with concrete roof) and rest of 6 $(12 \%)$ respondents had semi-concrete (Concrete wall and tin shed roof) house (Figure 5).

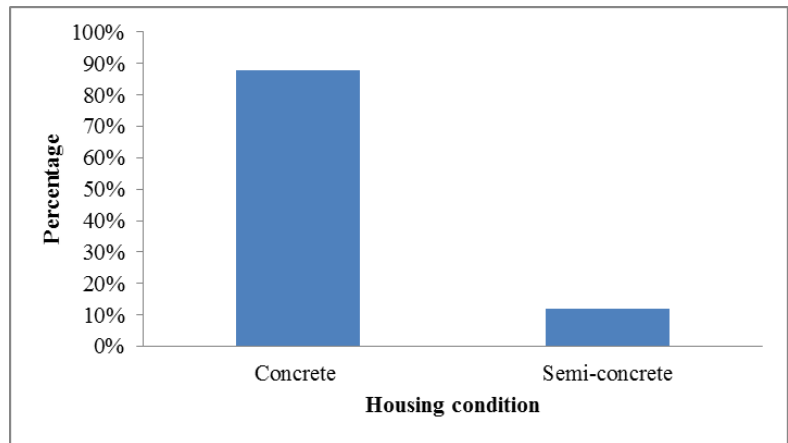

Figure 5. Housing status of pond fish farmers in the study area. 
3.7. Sanitation facilities

In the study area it was found that $100 \%$ farmer had a good sanitation facility. Almost 22 (44\%) farmers used concrete (concrete platform) toilet and rest of 28 (56\%) farmers used semi- concrete (concrete platform with tin shed) toilet (Figure 6).

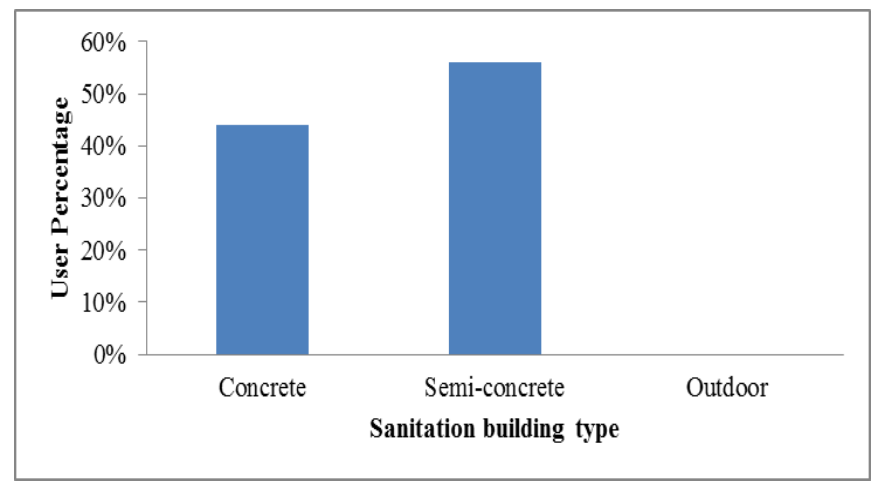

Figure 6. Sanitation facilities of farmer in Jhikargachha upazila, Jessore.

\subsection{Drinking water sources}

All the 50 respondents (100\%) were used to drink tube well water and other household work. Every farmer had at least one tube well in the house premises (Table 3).

Table 3. Drinking water source of farmer in Jhikargachha upazila, Jessore.

\begin{tabular}{lll}
\hline Water source & No. of respondents & Respondents $(\boldsymbol{\%})$ \\
\hline Tube well & 50 & 100 \\
Other & 0 & 0 \\
Total & $\mathbf{5 0}$ & $\mathbf{1 0 0}$ \\
\hline
\end{tabular}

\subsection{Educational status of fish farmers}

There were six categories used to determine the level of education. Out of 50 fish farmers, $4 \%$ had no education (illiterate), $36 \%$ had primary level, $42 \%$ had secondary level (up to X), $10 \%$ had S.S.C. level, $4 \%$ had H.S.C. level and $4 \%$ had bachelor level of education (Figure 7).

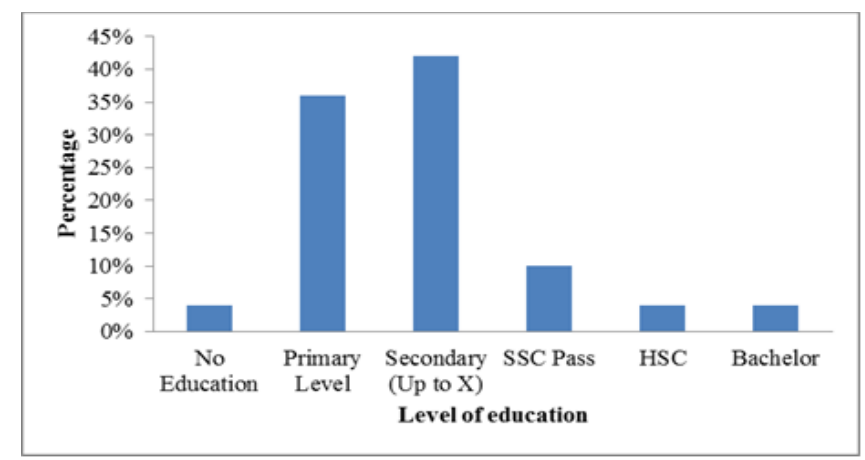

Figure 7. Educational status of fish farmers in Jhikargachha upazila.

\subsection{Farmer's children education status}

In the study area, $9(18 \%)$ farmer's children had primary education, $33(66 \%)$ farmer's children had secondary level, 6 (12\%) farmer's children had higher secondary level and rest $2(4 \%)$ farmer's children had bachelor level of education (Figure 8). 


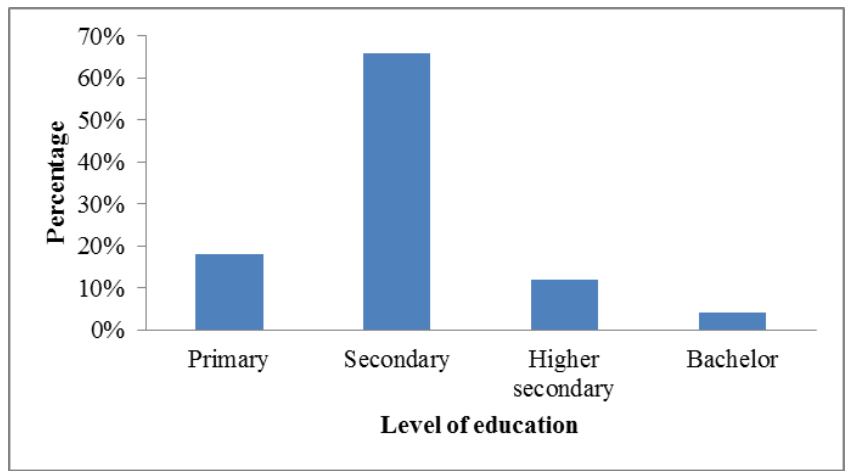

Figure 8. Farmer's children education status in Jhikargachha upazila, Jessore.

\subsection{Size of the pond of fish farmers}

Among the 50 farmer, most of them (32\%) had ponds with size of 34-66 dec. On the other hand, 14 (28\%) farmers had 15-33 dec. ponds, $14 \%$ had up to 100 dec., $22 \%$ had 101-330 dec. and 4\% had 330-above decimal ponds (Table 4).

Table 4. Pond area of farmer in Jhikargachha upazila, Jessore.

\begin{tabular}{lll}
\hline Pond size (decimal) & No. of respondents & Respondents (\%) \\
\hline $15-33$ & 14 & 28 \\
$34-66$ & 16 & 32 \\
$67-100$ & 7 & 14 \\
$101-330$ & 11 & 22 \\
$331-$ Above & 2 & 4 \\
Total & $\mathbf{5 0}$ & $\mathbf{1 0 0}$ \\
\hline
\end{tabular}

3.12. Training of fish farmers

In the study areas, all the selected farmers (Table 5) received training on fish poly culture from the local NGO named BRAC, ASA and ANSER; government organization like Department of Fisheries (DoF) and Upazila Fisheries officer (UFO). It was found that 31 (62\%) farmers had training on fish farming and rest 19 (38\%) farmers had no training on fish farming (Table 5).

Table 5. Receiving of training of fish farmers in Jhikargachha upazila, Jessore.

\begin{tabular}{lll}
\hline Training receive & No. of respondents & Respondents $(\boldsymbol{\%})$ \\
\hline Yes & 31 & 62 \\
No & 19 & 38 \\
Total & $\mathbf{5 0}$ & $\mathbf{1 0 0}$ \\
\hline
\end{tabular}

\subsection{Finance source}

It was found that $32(64 \%)$ farmers used to invest their own credit. And rest of 18 (36\%) farmers used money taken from bank, NGO, money lender and broker agency as a loan. The overall interest percentage of money in Jhikargachha upazila was 7\% (Figure 9). 


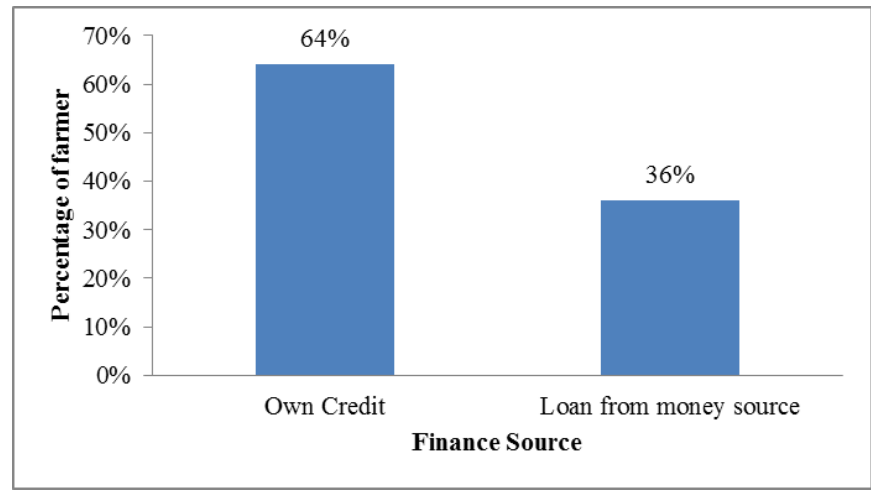

Figure 9. Finance source of farmer.

\subsection{Fish stocked by farmers}

Among 50 farmers, most of the farmers stocked and cultured rui (Labeo rohita), catla (Catla catla) and mrigal (Cirrhinus cirrhosus). The other species like bata (Labeo bata) was stocked by 43 farmers, silver carp (Hypophthalmichthys molitrix) was stocked by 44 farmers, grass Carp (Ctenopharyngodon idella) was stocked by 30 farmers, common carp (Cyprinus carpio) was stocked by 34 farmers, pangus (Pangasius hypophthalmus) was stocked by 25 farmers, mirror Carp (Cyprinus carpio) was stocked by 39 farmers, Tilapia (Oreochromis niloticus) was stocked by 32 farmers, monosex-tilapia was stocked by 1 farmer, scale carp (Cyprinus carpio) was stocked by 2 farmers, sarpunti (Puntius gonionotus) was stocked by 1 farmer, Bighead (Hypophthalmichthys nobilis) was stocked by 22 farmers and tengra (Mystus tengara) was stocked by 10 farmers in farm ponds (Figure 10).

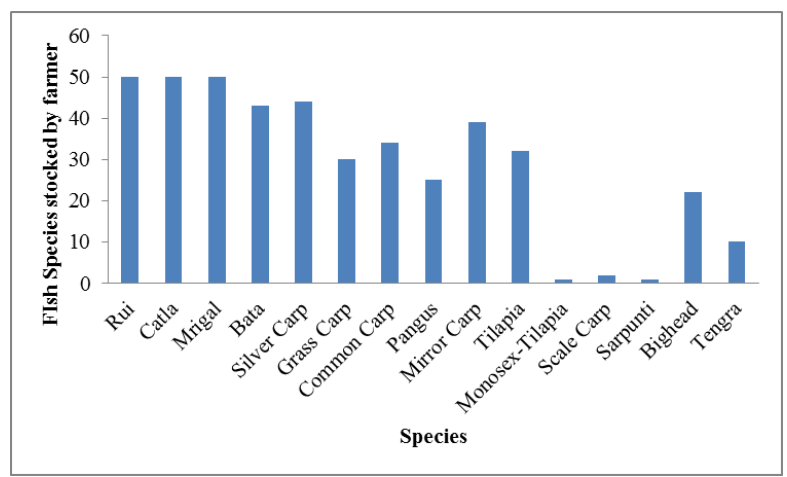

Figure 10. Fish Species stocked and cultured in Jhikargachha upazila, Jessore.

\subsection{Feed types preferred by farmers}

It was found that $72 \%$ (36) of the farmers applied supplementary and homemade feed prepared with rice-bran and mustard oil cake and 28\% (14) farmers used company made commercial feed (Figure 11).

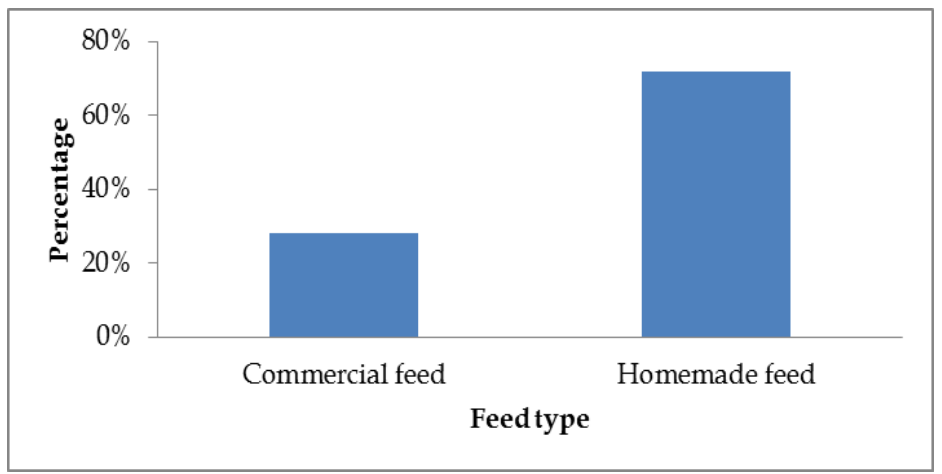

Figure 11. Feed preferred by fish farmers in Jhikargachha upazila, Jessore. 
3.16. Fertilizer used in fish farming

In the study area, cowdung was used by $50(100 \%)$ farmers. Urea was used by 47 farmers, TSP (Triple super phosphate) was used by 40 farmers and MoP (Murate of Potash) was used by 34 farmers (Figure 12).

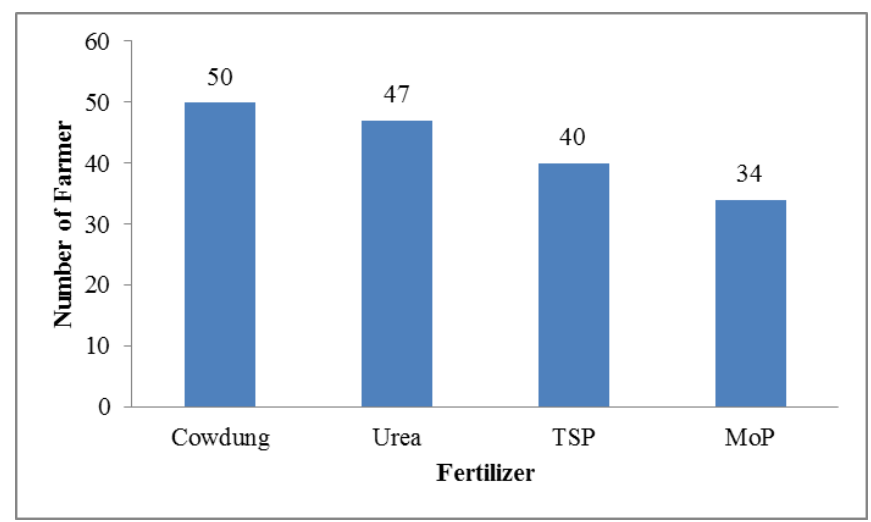

Figure 12. Fertilizer used by farmers.

\subsection{Grow out time of fish allowed by farmer}

During the interview periods every farmer responds that, they allowed to grow fish in their pond was to 6 month or more.

\subsection{Production of Fish}

Fish production was continuously increasing in the surveyed area because of gaining knowledge on fish culture. The highest production was measured as $27000 \mathrm{~kg} / \mathrm{year}$ and the lowest production was $650 \mathrm{~kg} / \mathrm{year}$. It was found that there were $4(8 \%)$ farmers produced $600 \mathrm{~kg}-1000 \mathrm{~kg} / \mathrm{year}, 20(40 \%)$ farmers produced $1001 \mathrm{~kg}-$ $2000 \mathrm{~kg} /$ year, 9 (18\%) farmers produced $2001 \mathrm{~kg}-3000 \mathrm{~kg} / \mathrm{year}$, and 17 (34\%) farmers produced $3001 \mathrm{~kg}$ above/year in the study area (Table 6).

Table 6. Average fish production of 30 ponds in Jhikargachha upazila, Jessore.

\begin{tabular}{lll}
\hline Average production (kg/year) & No. of respondents & Respondents (\%) \\
\hline $600-1000$ & 4 & 8 \\
$1001-2000$ & 20 & 40 \\
$2001-3000$ & 9 & 18 \\
$3001-$ Above & 17 & 34 \\
\hline
\end{tabular}

\subsection{Annual income}

The highest income was $33075000 \mathrm{Tk} / \mathrm{year}$ and the lowest income from a pond was $20000 \mathrm{Tk} / \mathrm{year}$. Among 50 farmers, almost $28(56 \%)$ farmers got their annual income as $100001 \mathrm{Tk}$ to $500000 \mathrm{Tk}$ and $5(10 \%)$ farmers got their annual income as $500001 \mathrm{Tk}$ to 1000000 (Figure 13).

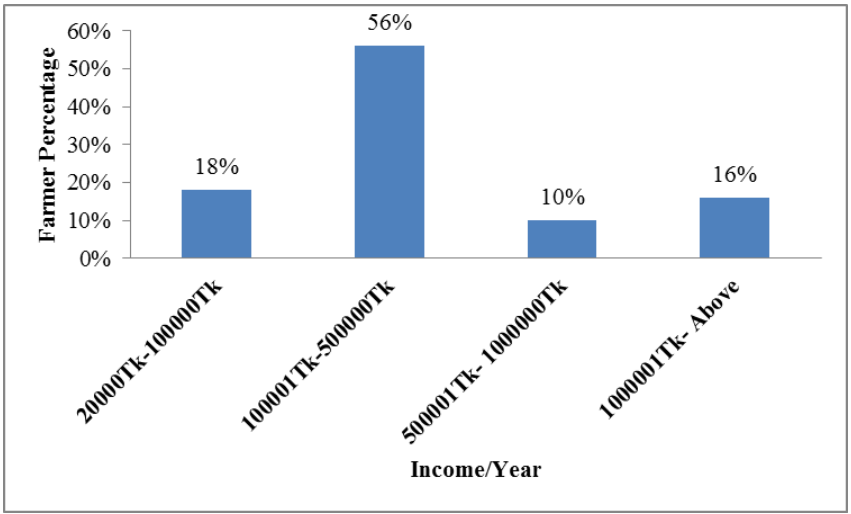

Figure 13. Annual income pattern of 50 pond farmers under four culture systems. 
3.20. Public or private bank account status of farmer

It was found that every farmer had at least one bank account. Some farmers had more than one account. In rural area BKash, Dutch-Bangla Bank, MCash, OK cash and other mobile banking were too much popular for any amount of transaction.

\subsection{Mobile phone used by farmers}

In the study area, it was found that every farmer had at least one mobile phone. Some farmer had more than one. They usually consulted with feed dealers, fertilizer dealers, NGO workers, technical service providers along with government official through mobile phone.

\subsection{Health status of farmers and their family}

It was found that $48(96 \%)$ farmers were used to go MBBS doctor or allopathic treatment and only $2(4 \%)$ farmers were used to go to homeopathic treatment (Figure 14).

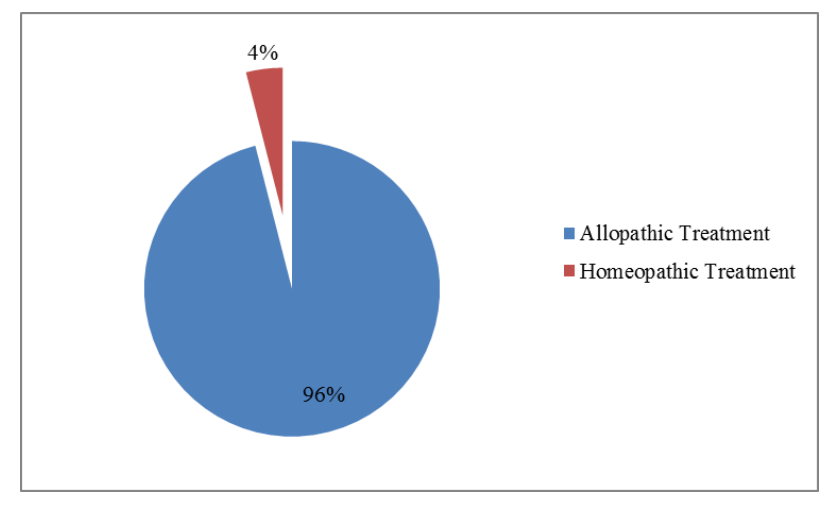

Figure 14. Health treatment status of farmers.

\subsection{Problems faced by the fish farmers}

A number of constraints and risks were reported by the farmers. Every farmer responds these problems. These problems are diseases; lack of proper management; theft; lack of quality fish fry; cheating of fry traders and multiple ownerships of ponds.

\section{Discussion}

The present study observed that, the highest number of fish farmer's age were 50 to 60 year $(38 \%)$ and lowest age (30\%) were 30-40 years. Khatun et al. (2013) reported that the age group of 36-50 years was the highest (46\%) and 51-65 years were the lowest (26\%) considering all fish farmers. This result is more or less relevant to the present study. Rana (1996) found in his study in Sirajgonj district that 70\% of pond farmers were in 18-45 years. Ali et al. (2009) found that most of the fish farmers (50\%) belonged to age group of 31 to 40 years in Mymensingh district. The more or less relevant study were conducted by Islam et al. (2017); Rahman et al. (2017); Hossain et al. (2015); Asif et al. (2015); Islam et al. (2014); Hossain et al. (2016); Sharif et al. (2015); Islam et al. (2015); Ali et al. (2016); Rahaman et al. (2015); Sharif et al. (2016) and Ahsan et al. (2016). Present study observed that, $44(88 \%)$ farmers were Muslims and $6(12 \%)$ farmers were Hindu in the present study. Khatun et al. (2013) mentioned, $82 \%$ of fish farmers were Muslims and $18 \%$ were Hindus. Islam (2012) observed that all the fish farmers $(100 \%)$ were Muslims which has similarity with the present study. Ali et al. (2008) was found that maximum fish farmers were Muslims (94\%) while small proportions (6\%) were hindus in some selected areas of Bagmara upazilla under Rajshahi district. Islam et al. (2015) investigated in Sundarban region $62 \%$ was muslim and $38 \%$ was Hindu. The more or less relevant study was conducted by Islam et al. (2017); Zaman et al. (2017); Hossain et al. (2015); Asif et al. (2015); Islam et al. (2014); Hossain et al. (2016); Sharif et al. (2015); Ali et al. (2016); Rahaman et al. (2015); Sharif et al. (2016) and Ahsan et al. (2016). Present study observed that aquaculture was not the primary occupation of most of the fish farmers. Only $82 \%$ involved in agriculture, rest of farmers were involved with business (8\%), service (4\%), politics (4\%) and rest of (2\%) farmers involved with daily labor work. These studies are more or less similar with the study of Ahmed (2003); Biswas (2003); Islam et al. (2014); Islam et al. (2017); Hossain et al. (2015); Asif et al. (2015); Islam et al. (2014); Hossain et al. (2016); Sharif et al. (2015); Islam et al. (2015); Ali et al. (2016); Rahaman et al. (2015); Sharif et al. (2016); Zaman et al. (2017); Ahsan et al. (2016) and Sen and Roy (2015). In the study of 
Jhikargachha, Jessore it was found that $66 \%$ fish farmers lived in joint families and $34 \%$ lived in separated families. Provakar et al. (2013) found that about 54\% of farmers lived in joint families and $46 \%$ in nuclear (seperated) families in Shahrasti upazila of Chandpur district. This result is not relevant to the present study. Ali et al. (2008) was found that about $28 \%$ farmers lived with joint families and $72 \%$ lived with nuclear families. Sharif et al. (2015); Ahsan et al. (2016) and Asif et al. (2015) stated the similar result with the present findings. It was found that around $13(26 \%)$ families had four members in their family, 9 (18\%) families had five members in their family, 16 (32\%) families had six members in their family and $12(24 \%)$ families had seven and more members. Hossain et al. (2015) found that $27 \%$ family had only 2-4 members. The highest $60 \%$ family has only 5-7 members. Halder (2002) recorded the largest family size (6.67 persons) was in Cast net fishermen and smallest family size (4.50 persons) was in hogra fishermen of Doba Beel. Most of the fish farmer (45\%) belonged in 4 to 5 member's family in Mymensingh district (Ali et al. 2009). Average members in the household of the fishermen were found $3.60 \pm 1.34$ by Islam et al. (2013) which has similarity with present findings. In present study, majority respondents $44(88 \%)$ had concrete house (concrete wall with concrete roof) and rest of 6 respondents (12\%) had semi-concrete (concrete wall and tin shed roof) house. Hossain et al. (2009) found that $40.3 \%$ of farmers' had house of earthen condition, $46.7 \%$ had semi-concrete and $10 \%$ had concrete house. However, at beel Chandpur, $36.67 \%, 56.67 \%$ and $6.67 \%$ farmer had earthen house, semi-concrete and concrete house respectively. Rahman (2003) reported that $70 \%$ of houses were earthen, while $21 \%$ were semiconcrete and only 9\% were concrete. Islam et al. (2017); Islam et al. (2014), Asif et al. (2015), Islam et al. (2015) and Sharif et al. (2015) did the same study. All the study is more or less similar with the present study. It was found that almost 22 (44\%) farmers used concrete (concreted platform) toilet and rest of $28(56 \%)$ farmers used semi- concrete (Concrete platform with tin shed) toilet. Sharif et al. (2015) found that 5\% concrete toilet, $50 \%$ has earthen toilet and 45\% semi concrete toilet. Asif et al. (2015) investigated in Jessore that about $69 \%$ and $31 \%$ of fish farmers used semi-concrete and concrete toilet respectively. All these study are more or less similar with the present study. All the respondents $50(100 \%)$ farmers used to drink tube well water and other household work. Hossain et al. (2015) found that $100 \%$ fishermen used tube-well water for drinking purpose. Sharif et al. (2015) described that about $97 \%$ fish farmers used tube well and rest $3 \%$ of the farmer uses pond water. This has more or less similarity with the present study. Education has a role in influencing yields through production decisions. Out of 50 fish farmers, $4 \%$ had no education (illiterate), $36 \%$ had primary level, $42 \%$ had secondary level (Up to X), 10\% had S.S.C. pass level, 4\% had H.S.C. level and 4\% had bachelor level of education. Provakar et al. (2013) found in his study in Shahrasti upazila of Chandpur district that about $10 \%$ had no education while $16 \%, 48 \%, 16 \%$ and $10 \%$ had primary, secondary, higher secondary and bachelor level of education, respectively. $23.3 \%$ farmers were illiterate whereas $14.4 \%, 8.9 \%$ and $6.7 \%$ were educated up to primary, secondary and higher secondary or above level, respectively. This study also has similarity with the findings of Hossain et al. (2009), Islam et al. (2014), Hossain et al. (2015), Asif et al. (2015), Islam et al. (2015); Zaman et al. (2017) and Sharif et al. (2015). In the present study, 9 (18\%) childrens of farmers had primary education, $33(66 \%)$ had secondary level, $6(12 \%)$ children had in higher secondary level and rest 2 (4\%) children of farmers had bachelor level. Hossain et al. (2015) investigated in Rajshahi that $64 \%$ of fishermen were found to send their children to school whereas $36 \%$ did not send children for schooling. These results are similar with the present (Asif et al., 2015 and Islam et al., 2014). Among the 50 farmer most of them $(32 \%)$ had the agricultural land (34-66 dec). On the other hand, $28 \%$ had $(15-33 \mathrm{dec}), 14 \%$ had up to $100 \mathrm{dec}$, $22 \%$ had (101-330 dec) and 4\% had (330-above dec). Provakar et al. (2013) reported that the average pond size of the area was $0.24 \mathrm{ha}(60 \mathrm{dec})$ in Shahrasti upazila of Chandpur district. This study is not similar to the present study. Khan (2012) revealed that the average pond size was 0.13 ha in Sreemongal upazila of Maulvibazar district which is not to similar to the present study. Islam (2011) reported that the average pond size was 0.16 ha with a range from 0.04 to 0.81 ha in some selected areas of Maulvibazar district. All the studies are more or less similar with the present study (Asif et al., 2014). It was found that, 62\% (31) farmer had training on fish farming and rest of 38\% (19) farmer had no training on fish farming. Sarwer et al. (2016) said that $18 \%$ received formal training from Upazila Fishery Office with the help of Department of Fisheries (DoF). Hossain et al. (2015) stated that only $20 \%$ fishermen had training on one or more than one related matter, $80 \%$ have no any training. These results differ with the findings of Biswas (2003) and Sultana (2001) study. Khatun et al. (2013) reported that $14 \%$ of farmers received training from DoF and $7 \%$ of farmers gain fish farming experience from relatives. It was found that $32(64 \%)$ farmer used to invest their own credit. And rest of 18 (36\%) farmers took loan from bank, NGO, money lender and broker agency. Sarwer et al. (2016) reported that $91 \%$ of the farmers used their own money for fish farming and $6 \%$ of the farmers received loan from bank for farming activities. $3 \%$ of the fish farmers received loan from other sources. Sharif et al. (2015) stated that $5 \%$ of finance are contributed by farmers, $73 \%$ farmers got finance from bank whereas $22 \%$ farmers took finance from local moneylenders. Asif 
et al. (2014) and Zaman et al. (2017) did similar research and got the relevant results. About $70 \%$ farmers fertilized ponds after removing of weeds. Along with rui, catla and mrigal the farmer used to stock other species like bata (43 farmers), silver carp (44 farmers), grass carp (30 farmers), common carp (34 farmers), pangus (25 farmers), mirror carp (39 farmers), tilapia (32 farmers), monosex-tilapia (1 farmer), scale carp (2 farmers), sarpunti ( 1 farmer), bighead carp (22 farmers) and tengra (10 farmers) were stocked. Ahmed (2003) observed that peak period of carp polyculture was from April to December. On the other hand, Tanjina (2011) stated that there were 17 available fish species under five orders found during the study period in Shinghorkhali beel in Dinajpur district. Ahmed (2003) also stated that there were about 15 different fish species found to culture in the farms of Naogaon district. Biswas (2003) stated that there were about 14 different fish species found to culture in the farms of Mymensingh district. Most of the farmers had small size pond where they used household waste, rice bran and mustard oil cake to feed fishes. Farmers increased the use of feeds as rice bran, mustard oil cake along with commercial feed. Provakar et al. (2013) found in Shahrasti upazila of Chandpur district that 95\% of the farmers applied supplementary feed such as rice bran, mustard oil cake and commercially manufactured feed and rest 5\% of farmers depended on the natural food in the pond. Alam (2006) found that $80 \%$ of the farmers applied supplementary feed such as rice bran and mustard oil cake. In the study area, cowdung was used by 50 $(100 \%)$ farmers. Urea was used by 47 farmers, TSP (Triple super phosphate) was used by 40 farmers and MoP (Murate of Potash) was used by 34 farmers. Saha et al. (2003) found that only 25\% farmers gave fertilizer in the pond which has no similarity with the present work. Saha (2004) observed that the average dose of inorganic fertilizer of urea was $387 \mathrm{~kg} / \mathrm{ha} / \mathrm{year}$ and TSP $176 \mathrm{~kg} / \mathrm{ha} / \mathrm{yr}$. Rahman (1998) found in his study that doses of organic and inorganic fertilizer were $11,075 \mathrm{~kg} / \mathrm{ha}$ and $739 \mathrm{~kg} / \mathrm{ha}$, respectively. This study is not equivalent with the present study. Rana (1996) found that farmers used organic fertilizer was $8,122 \mathrm{~kg} / \mathrm{ha} / \mathrm{year}$ and urea was 315 $\mathrm{kg} / \mathrm{ha} /$ year and TSP was $111 \mathrm{~kg} / \mathrm{ha} / \mathrm{yr}$. Zaman et al. (2017) also found the similar results with the present study. The highest production was $27000 \mathrm{~kg} / \mathrm{yr}$ and the lowest production was $650 \mathrm{~kg} / \mathrm{yr}$. It was found that, there were $4(8 \%)$ farmers produced 600-1000 kg/yr, 20 (40\%) farmers produced 1001-2000 kg/yr, 9 (18\%) farmers produced 2001-3000 kg/yr, and 17 (34\%) farmers produced 3001kg - above/yr during the study. This production is more or less similar with the study of Siddika et al. (2016); Hossain et al. (2014); Akter (2001) and Ali et al. (2015). The highest income was $33075000 \mathrm{Tk} / \mathrm{yr}$ and the lowest income from a pond was $20000 \mathrm{Tk} / \mathrm{yr}$. In the study area 9 (18\%) farmers got their annual income from 20000 to 100000 Tk. Almost 28 (56\%) farmers got their annual income from 100001 to $500000 \mathrm{Tk}$, some 5 (10\%) farmers got their annual income from $500001 \mathrm{Tk}$ to $1000000 \mathrm{Tk}$ and rest of $8(16 \%)$ farmers got their annual income from $1000001 \mathrm{Tk}$ to above. Provakar et al. (2013) stated that the highest (34\%) fish farmers earned 75,000 to 1,00000Tk per year in Shahrasti upazila of Chandpur district. Islam (2015) stated that the average fish production of $16.67 \%$ respondents were high (3188 $\mathrm{kg} / \mathrm{ha} / \mathrm{yr}), 33.33 \%$ respondents were medium $(2627 / \mathrm{kg} / \mathrm{ha} / \mathrm{yr}), 16.67 \%$ low $(1864 \mathrm{~kg} / \mathrm{ha} / \mathrm{yr})$ and $33.33 \%$ were very low $(1407 \mathrm{~kg} / \mathrm{ha} / \mathrm{yr})$ which is similar with the present study. It was found that, every farmer in the study area had at least one bank account. Some farmers had more than one account for saving money and money transaction. BKash, Dutch-Bangla Bank, MCash, OK cash and other mobile banking was too popular for any amount of transaction in the study area. Zaman et al. (2017); Asif et al. (2015) and Sharif et al. (2015) did the same study and their findings are more relevant with the present study. It was found that $100 \%$ farmers had one or more mobile phone. Which is similar with the findings of Asif et al. (2015) and Sharif et al. (2015). It was found that $48(96 \%)$ farmers were visited MBBS doctor or took allopathic treatment and only $2(4 \%)$ of farmer were used to go to homeopathic treatment which is relevant with the findings of Zaman et al. (2017); Siddika $e t$ al. (2016); Islam et al. (2014); Sharif et al. (2015); Islam et al. (2015); Hossain et al. (2014) and Ali et al. (2015).

From the survey, it was found that diseases, theft, shadow of trees, fallen leaves of tree, multiple ownership, lack of quality feed, lack of quality fish fry, water contamination by human baths and clothes washing, rapid water decrease in dry season, dike erosion in rainy season, snakes ate fishes in the pond etc were the major problems of fish production. Ali et al. (2009) and Ali et al. (2015) reported that lack of scientific knowledge, multiple ownership of ponds, attack of fish disease and non-availability of good quality fish fry were the major problems in pond fish culture in Bangladesh. Mollah et al. (1990) conducted that the farmers have major constraints as; $72.50 \%$ of farmers reported theft was one of the main problems followed by financial problem (40\%), lack of contact with fisheries officer (37.75\%), lack of fish seeds (27.50\%) and lack of feeds (23.75\%) which hampered the production in Laxmipur district which has no similarity with the present study. The similar study on prospects and constrains were conducted by Shabuj et al. (2016); Chowdhury et al. (2015); Sharif et al. (2015); Yeasmin et al. (2015); Razeim et al. (2017); Rahman et al. (2015); Rahman et al. (2017); Hossain et al. (2016); Islam et al. (2017); Shabuj et al. (2015); Islam et al. (2015); Islam et al. (2016) and Hossain et al. (2017). 


\section{Conclusions}

Generally fish farming played a vital role in the uplifting of the life style and socio-economic condition of fish farmer of Jhikargachha upazila. From the results of present study, it can be concluded that fish culture has broad socio-economic benefits for the fish farmers. If the farmers are given precious training, economic support on easy terms and conditions, more profit would be outputted. Thus it can be concluded that fish farming is a fruitful business that can help the peasant to uplift their livelihood situation as well as economic criteria. This study also explored some major problems which were faced by the local people after starting the fish culture. From the survey, it was found that diseases, lack of proper management, theft, multiple ownership and lack of quality fish fry etc. were the major problems of fish production.

\section{Conflict of interest}

None to declare.

\section{References}

Ahmed F, 2003. Comparative study on carp polyculture practices of three different NGOs in Mymensingh district. M.S. thesis, Department of Fisheries Management, Bangladesh Agricultural University, Mymensingh.

Ahmed N and MM Rahman, 2005. A study on fish marketing system in Gazipur, Bangladesh. Pak. J. of Biol. Sci., 8: 287-292.

Ahsan MK, NS Runa, SK Ghosh, MM Hasan and M Kamal, 2016. Socio-economic condition of fishermen and intermediaries involved in marine fish marketing chain in Cox's Bazar area, Bangladesh. Asian J. Med. Biol. Res., 2: 67-73.

Akter N, 2001. An economic analysis of pond pangas fish production in a selected area of TrishalUpazila in Mymensingh District.MS Thesis, Department of Agricultural Economics, BAU, Mymensingh.

Alam G, 2006. Status of fish farming and livelihoods of fish farmers in some selected areas of MithapuqurUpazila in Rangpur district, An M.S. Thesis, Department of Fisheries Management, Bangladesh Agriculture University, Mymensingh.

Ali H, MAK Azad, M Anisuzzaman, MMR Chowdhury, M Hoque and MI Sharful, 2009. Livelihood status of the fish farmers in some selected areas of Tarakanda upazila of Mymensingh district. J. Agrofor. Environ., 3: 85-89.

Ali MH, MD Hossain, ANGM Hasan and MA Bashar, 2008. Assesment of the livelihood status of the fish farmers in some selected areas of BagmaraUpazila under Rajshahi district. J. Bangladesh Agril. Univ., 6: 367-374.

Ali MM, AA Asif, MAI Shabuj, S Vaumik, MA Zafar and BMN Sharif, 2016.Status of polyculture Pangasius hypophthalmus with carps in Jhikargacha upazila of Jessore district, Bangladesh. Int. J. Fish. Aquat. Stud., 4: 423-430.

Ali MY, R Rahmatullah, M Asadujjaman, MGU Bablu and MG Sarwer, 2015. Impacts of banning period on the socio-economic condition of hilsa fishermen in shakhchor union of lakshmipursadarupazila, Bangladesh. Middle-East J. Sci. Res., 23: 2479-2483.

Ara Y, 2005. Assessment of small scale fresh water fish farming for sustainable livelihoods of the rural poor farmers. M.S. Thesis, Department of Fisheries Management, Bangladesh Agricultural University, Mymensingh.

Asif AA, MA Samad, BMS Rahman, MA Rahman, MH Rahman, SM Yeasmin and A Nima, 2014. Study on management of fish fry and fingerling marketing of Jessore in Bangladesh. International Journal of Business, Social and Scientific Research, 2: 127-135.

Asif AA, MA Samad, MH Rahman, MA Farid, SM Yeasmin, BMS Rahman and A Nima, 2015. Socioeconomic condition of fish fry and fingerling traders in greater Jessore region. Int. J. Fish. Aquat. Stud., 2: 290-293.

Bangladesh Economic Review, 2015. Finance division, Ministry of finance, Government of the people's republic of Bangladesh.

BBS, 2014. Statistical year book of Bangladesh. Bangladesh Bureau of Statistics, Statistical Division, Government of People's Republic of Bangladesh, Dhaka, 60-115 pp.

Biswas D, 2003. Study of the impacts of aquaculture in and around fish farms in Mymensingh District. MS Thesis. Department of Aquaculture, Bangladesh Agricultural University, Mymensingh.

Chowdhury AA, MS Uddin, S Vaumik and AA Asif, 2015. Aqua drugs and chemicals used in aquaculture of Zakigonjupazilla, Sylhet. Asian J. Med. Biol. Res., 1: 336-349. 
DFID, 1998. Sustainable livelihoods guidance sheets, Department for International Development (DFID), London, UK.

DoF, 2015. Jatio Matshaw Saptaha Sankalan 2015. Department of Fisheries, Ministry of Fisheries and Livestock, Bangladesh, 18-37 pp.

Export Promotion Bureau, 2014. Annual export report.Ministry of Commerce, TCB Bhaban, 1, Kawran Bazar $\left(2^{\text {nd }}\right.$ and $4^{\text {th }}$ Floor $)$ Dhaka-1215, Bangladesh.

Halder DK, 2002. Studies on the availability of small indigenous species (SIS) of fishes and socioeconomic condition of fishers in two rice fields. M.S. Thesis. Department of Fisheries Management, BAU, Mymensingh.

Haque MZ, MA Rahman and MS Shah, 1991. Studies on the density of Rohu (Labeorohita) fingerlings in polythene bags for transportation. Ban. J. Fish., 14: 145-148.

Hossain A, MAR Hossain, AA Asif, S Ahmed and A Satter, 2017. Fish fermentation in Lalpur, Brahmanbaria district: ecological implication and value chain analysis. Asian Australas. J. Biosci. Biotechnol., 2:159-172.

Hossain FI, MI Miah, MHA Hosen, R Pervin and MR Haque, 2015. Study on the socio-economic condition of fishermen of the punorvaba river under sadar upazila, Dinajpur. Journal of Fisheries, 3: 239-244.

Hossain MA, AA Asif, MA Zafar, MT Hossain, MS Alam and MA Islam, 2015. Marketing of fish and fishery products in Dinajpur and livelihoods of the fish retailers. Int. J. Fish. Aquat. Stud., 3: 86-92.

Hossain MI, C Siwar, MB Mokhtar, MM Dey and AH Jaafar, 2009. Socio-economic condition of fishermen in seasonal floodplain beels in Rajshahi district, Bangladesh. Res. J. Soc. Sci., 4: 74-81.

Hossain MT, MS Alam, MH Rahman, AA Asif and SM Rahmatullah, 2016. Present status of Indian major carp brood stock management at the hatcheries in Jessore region of Bangladesh. Asian Australas. J. Biosci. Biotechnol., 1: 362-370.

Hossain MZ, A Pal, MA Hasan, MS Parvej, N Nahar and AA Asif, 2016. Nutritional status and sociodemographic characteristics of the people of south-west coastal region in Bangladesh. Asian Australas. J. Biosci. Biotechnol., 1: 323-332.

Hossain S, MT Hasan, MT Alam and SK Mazumder, 2014. Socio-economic condition of the fishermen in jelepara under pahartoli of Chittagong district. J. Sylhet Agril. Univ., 1: 65-72.

Hughes RS, Adnan and B Dalal-Clayton, 1994. Floodplains or flood plans. International Institute for Environment and Development and Research and Advisory services, London, $77 \mathrm{pp}$.

Islam FMK, AA Asif, M Ahmed, MS Islam, B Sarker, MA Zafar and M Rahman, 2017. Performances of resource poor households in aquaculture practices in sadarupazila, Meherpur, Bangladesh. Int. J. Fish. Aquat. Stud., 5: 281-288.

Islam MA, AA Asif, MA Samad, BMS Rahman, MH Rahman, A Nima and SM Yeasmin, 2014. Socioeconomic conditions of the fish farmers in Jessore, Bangladesh. International Journal of Business, Social and Scientific Research, 2: 153-160.

Islam MM, AA Asif and MR Amin, 2016. The induced breeding of common carps (Cyprinus carpio) in Bangladesh. Indian Journal of Science, 23: 619-632.

Islam MM, AA Asif, S Vaumik, MA Zafar, BMN Sharif, MH Rahman and S Shahriyar, 2015.Socio Economic Status of Fry Collectors at Sundarban Region. Int. J. Fish. Aquat. Stud., 3: 89-94.

Islam MR, MJH Biswas, MGR Akanda, MR Amin, IM Hasan, AA Asif, S Sheheli and BMN Sharif, 2015. Attitude of the farmers towards climate change effect on agriculture. Asian J. Med. Biol. Res., 1: 367-379.

Islam MR, MN Hoque, SM Galib and MA Rahman, 2013. Livelihood of the fishermen in MonirampurUpazila of Jessore district. Bangladesh. J. Fish., 1: 37-41.

Islam MS, AA Asif, B Sarker, A Satter, M Ahmed, M Rahman, MA Zafar and SM Rahmatullah, 2017. Fry production and its marketing system of North-West fisheries extension project at Parbatipur, Dinajpur, Bangladesh. Asian J. Med. Biol. Res., 3: 368-378.

Islam MS, SMM Murshed, M Moniruzzaman and MA Baree, 2002. Rice-cum fish farming in selected areas of Mymensingh District. Journal of Biological Sciences, 2: 715-718.

Islam S, 2011. Studies on pond fish farming and livelihoods of rural farmers in some selected areas of Maulvibazar District. MS Thesis, Department of Aquaculture, Bangladesh Agricultural University, Mymensingh.

Khatun S, RK Adhikary, M Rahman, MNA Sikder and MB Hossain, 2013.Socio-economic status of pond fish Farmers of charbata, Noakhali, Bangladesh. Int. J. Life Sci. Biotec. Phar. Res., 2: 356-365.

Mahfuj MSE, MB Hossain, and MH Minar, 2012. Biochemical composition of an endangered fish, Labeo bata (Hamilton, 1822) from Bangladesh water. Am. J. Food Tech., 7: 633-641. 
Mollah AR, SNI Chowdhury and MAB Habib, 1990. Input output relationship in fish production under various pond sizes, ownership pattern and constraints. Bangl. J. Tra. Dev., 3: 87-101.

Rahaman MM, MA Zafar, BMN Sharif, P Paul, AA Asif, MM Islam and MI Hossain, 2015.Tilapia Oreochromismossambicus marketing system in greater Jessore region, Bangladesh. Int. J. Fish. Aquat. Stud., 3:95-103.

Rahman H, JA Mirza, AHossain, AA Asif, E Haq, P Chwakravorty and M Rahman, 2017. Economics of fish production in paddy fields in Bangladesh. Asian J. Med. Biol. Res., 3: 379-390.

Rahman MA, MH Rahman, SM Yeasmin, AA Asif and D Mridha, 2017. Identification of causative agent for fungal infection and effect of disinfectants on hatching and survival rate of bata Labeo bata larvae. Adv. Plants Agric. Res., 7: 00264.

Rahman MH, MA Rahman, MMM Hossain, SM Yeasmin and AA Asif, 2015. Effect of feeding management of broodstock on breeding performance of bata Labeo bata. Asian J. Med. Biol. Res., 1: 553-568.

Rahman MM, 1998. An economic study of ponds fish culture in some selected area of Mymensingh District.MS Thesis, Department of Agricultural Economics, Bangladesh Agricultural University, Mymensingh.

Rahman MM, 2003. Socioeconomic aspects of carp culture development in Gazipur Bangladesh. MS Thesis submitted to the Department of Fisheries Management, BAU, Mymensingh.

Rana MS, 1996. An Economic Analysis of Pond fish Culture in some selected areas of Sirajgonj district, MS Thesis, Department of Agricultural Economics, BAU, Mymensingh.

Razeim MA, MG Farouque, MA Sarker, AA Asif and M Ahmed, 2017. Attitude of farmers towards Pangas farming for their livelihood improvement. Asian Australas. J. Biosci. Biotechnol., 2:106-119.

Saha MK, 2003. A study on fish production technology in North-West Bangladesh.MS thesis, Department of Aquaculture, BAU, Mymensingh.

Saha SR, 2004. Status of pangasiid catfish (Pangasius hypophthalmus) farming in Mymensingh region. MS Thesis, Department of Fisheries Management, BAU, Mymensingh.

Sarwer MG, MY Ali, S Bhowmik, M Asadujjaman and MS Sharmin, 2016. Pond Farming and Livelihood Status of Fish Farmers in Subarnachar, Noakhali, Bangladesh. Agric. Biol. J. N. Am., 7: 134-139.

Sen A and M Roy, 2015. Socio-economic status of fish farmers in Tripura, India. Int. J. Cur. Res., 7: 1709017096.

Shabuj MAI, AA Asif, O Faruq, MR Bari and MA Rahman, 2016. Brood stock management and induced breeding of Thai pangus Pangasius hypophthalmus practiced in the hatcheries of Jessore Region, Bangladesh. International Journal of Business, Social and Scientific Research, 4: 235-246.

Shabuj MAI, T Bairagi, AA Asif, O Faruq, MR Bari and MS Neowajh, 2015. Shrimp disease investigation and culture strategies in Bagerhat district, Bangladesh. Asian J. Med. Biol. Res., 1: 545-552.

Sharif BMN and AA Asif, 2015. A Present status of fish hatchlings and fry production management in greater Jessore, Bangladesh. Int. J. Fish. Aquat. Stud., 2:123-127.

Sharif BMN, AA Asif, S Vaumik, MA Zafar, MM Islam and MA Samad, 2015. Socio-economic condition of fish farmer and trader at the village of Pitamborpur in Chaugachha upazilla in Jessore, Bangladesh. Int. J. Fish. Aquat. Stud., 3: 212-217.

Sharif BMN, MY Ali, MK Saha, MA Ahmad, MA Islam and MR Amin, 2016. Economic analysis of the fishery activities of Bergobindapur baor at Chaugachha upazila under Jessore district of Bangladesh. Asian J. Med. Biol. Res., 2: 436-441.

Siddika T, RK Adhikary, MHU Jaman, S Khondoker, N Tabassum, MFU Zaman, 2016. Socio Economic Conditions of the Hatchery Labors in Chanchra Area of Jessor District in Bangladesh. Agriculture, Forestry and Fisheries, 5: 30-36.

Sultana S, 2001. Socioeconomic Impact of the Adopting of BFRI Involved Polyculture and Carp Nursery Technologies in some selected areas of TrishalUpazila in Mymensingh District, MS Thesis, Department of Agricultural Economics, BAU, Mymensingh.

Tanjina M, 2011. A study on problems of Shinghorkhalibeel in Dinajpur District.MS Thesis, Department of Fisheries Management, Bangladesh Agricultural University, Mymensingh.

Yeasmin SM, MA Rahman, MMM Hossain, MH Rahman and AA Asif, 2015. Identification of causative agent for fungal infection and effect of disinfectants on hatching and survival rate of common carp C. carpio larvae. Asian J. Med. Biol. Res., 1:578-588.

Zaman MFU, MA Samad, MA Islam, MHU Jaman, S Khondoker and AA Asif, 2017. Assessment of sustainability of Pangasius (Pangasiushypophthalmus) farming at Jhikargachhaupazila in Jessore district, Bangladesh. International Journal of Fauna and Biological Studies, 4: 109-119. 